\title{
COLLISION COURSE
}


The Institute of Southeast Asian Studies (ISEAS) was established as an autonomous organisation in 1968. It is a regional research centre for scholars and other specialists concerned with modern Southeast Asia, particularly the many-faceted problems of stability and security, economic development, and political and social change.

The Institute's research programmes are the Regional Economic Studies Programme (RES), Regional Strategic and Political Studies Programme (RSPS), Regional Social and Cultural Studies Programme (RSCS), and the Indochina Programme (ICP).

The Institute is governed by a twenty-two-member Board of Trustees comprising nominees from the Singapore Government, the National University of Singapore, the various Chambers of Commerce, and professional and civic organisations. A ten-man Executive Committee oversees day-to-day operations; it is chaired by the Director, the Institute's chief academic and administrative officer. 


\title{
COLLISION COURSE
}

America and East Asia

in the Past

and the Future

\author{
BRYCE HARLAND
}

INSTITUTE OF SOUTHEAST ASIAN STUDIES

Singapore 
Published by

Institute of Southeast Asian Studies

Heng Mui Keng Terrace

Pasir Panjang

Singapore 119596

Internet e-mail: publish @ merlion.iseas.ac.sg

WWW: http://merlion.iseas.ac.sg/pub.htmi

All rights reserved. No part of this publication may be reproduced, stored in a retrieval system, or transmitted in any form or by any means. electronic, mechanical, photocopying, recording or otherwise, without the prior permission of the Institute of Southeast Asian Studies.

(1) 1996 Institute of Southeast Asian Studies, Singapore

The responsibility for facts and opinions in this publication rests exclusively with the author and his interpretations do not necessarily reflect the views or the policy of the Institute or its supporters.

\section{Cataloguing in Publication Data}

Harland, Bryce.

Collision course: America and East Asia in the past and the future.

1. East Asia - Foreign relations - United States.

2. United States - Foreign relations - East Asia.

3. Vietnamese Conflict, 1961-1975 - United States.

I. Titles.

DS33.4 U6H28

1996

sls $96-22480$

ISBN 981-3055-30-8 (soft)

ISBN 981-3055-37-5 (hard)

Typeset by Superskill Graphics Pte Ltd

Printed and bound in Singapore by Prime Packaging Industries Pte Lid. 
For Annie

and

Toz 
